\title{
Air pollution impacts from open air burning
}

\author{
B. Sivertsen \\ NILU, Kjeller, Norway
}

\begin{abstract}
As part of the air quality monitoring and assessment, emissions from the open air burning of waste and biomass have proven important sources of impact on the population exposure. The emissions of a variety of air pollutants from different types of open-air burning have been evaluated. Simple model estimates are used to estimate the impact in areas downwind from backyard burning. Different models have been used to estimate the importance of impact and the reasons for odours detected downwind from waste dumping areas.

Data from Cairo and other major cities have been used to estimate the impact of emissions from agricultural waste burning. In several urban areas especially in developing countries the contribution to the PM exposure has been demonstrated to range between 30 and $50 \%$ dependent upon weather conditions. The design and application of combined monitoring programmes and models may be part of the systematic evaluation of impacts and optimal control of the sources. Keywords: air pollution, waste burning.
\end{abstract}

\section{Introduction}

Waste is a growing environmental, social and economic issue for all modern economies. Waste volumes are increasing at rates equalling and sometimes outpacing economic growth. The way that waste is generated and handled has an impact on everyone, from individual citizens and small businesses to public authorities and international trade.

The generation of more and more waste is a symptom of inefficient use of resources, which should actually have been utilised in a better way as a resource for energy and materials. The air pollution generated from waste causes impacts felt by a large part of the population living in and around major urban areas. The pollutants are partly emitted due to leakages and evaporation of gases causing 
annoying smells and partly generated by self-burning or active fires onset by humans at dumpsites.

In the following we will discuss emissions to the atmosphere and exposure to humans caused by dump sites, burning of household-, garden and agricultural waste as well as pollutants due to the use of waste in small industries.

\section{Estimated emissions to the atmosphere}

Air pollution emissions from waste deposits can be generated through leakages of gases or from combustion when waste is being burned. One of the major concerns at dumpsites is the leakage of methane and other green house gases. This subject will, however, not be covered in this paper.

The complete combustion and open air burning of waste require sufficient heat flux, adequate oxygen supply, and sufficient burning time. The size and quantity of the emissions of different compounds from this type of burning depends on a number of factors such as density, moisture and wetness, topography (slope and profile of underlying ground) and meteorological conditions (wind, precipitation etc.)

\subsection{Waste deposit areas and dumps}

From an environmental perspective, dumping or 'land filling' is the worst waste management option. It uses up space and creates a future environmental liability. It represents a waste of resources. European legislation has introduced high standards for landfills to prevent soil and groundwater pollution, and to reduce emissions to air; for example of methane and other air pollutants. In some cases the legislation is poorly implemented and there are still thousands of mismanaged and unauthorised landfills across the member states.

Because of their high vapour pressures and low solubility, many toxic VOCs are observed in landfill gas. In a report by the State of California Air Resources Board, the average surface emission rate of hazardous chemicals was estimated to be $35 \mathrm{~kg}$ per million $\mathrm{kg}$ of refuse (Bennett [3]).

Numerous investigations have been conducted with the objective of characterizing landfill gas emissions. Significant variation in landfill gas composition has been observed. A number of environmental parameters influence the production rate and the composition of landfill gas. The main factors are waste composition, time since placement, $\mathrm{pH}$, moisture content, availability of nutrients, and soil type.

Temperature is also a key variable. Within a few days of placement, the temperature in the dump will rise due to aerobic decomposition. Intensive reduction of organic matter by putrefaction is usually accompanied by disagreeable odours of hydrogen sulphide and reduced organic compounds which contain sulphur, such as mercaptans. After the oxygen is depleted, the temperature drops back again because anaerobic processes are slower and less 
energetic. The optimal temperature for the production of methane and other organic pollutants is between 32 and $38^{\circ} \mathrm{C}$ (Cooper et al. [7]).

NILU measured gases released from a landfill outside Oslo in 1989 (Braathen and Schmidbauer [5]). Samples were taken at 7 locations of VOC, Volatile aldehydes, $\mathrm{H}_{2} \mathrm{~S}$ and methanthiol. Concentrations measured at the side of the landfill were much higher than on top of the dump. It was thus concluded that most of the odours identified in the surrounding areas was due to old waste.

In other studies ethyl benzene was found at concentrations more than 20 times the detection threshold $\left(\mathrm{OU}_{50 \mathrm{D}}\right)$. The $\mathrm{H}_{2} \mathrm{~S}$ concentrations on top of the deposit were between 120 and $450 \mu \mathrm{g} / \mathrm{m}^{3}$.

Tønnessen [16] performed a specific study on a landfill to identify the reasons for complaints about odours in the surrounding areas. Calculations of gas emissions and dispersion of odorous gases were based upon measurements and models. At this specific site measurements showed that $\mathrm{H}_{2} \mathrm{~S}$ was the odorous component with highest release rate compared to the odour threshold.

At this relatively small deposit area, where 60,000 tons were deposited every year, the total amount of gases released was estimated at $590 \mathrm{~m}^{3} / \mathrm{h}$. Measurements indicated average concentrations of $\mathrm{H}_{2} \mathrm{~S}$ at $0.9 \pm 0.47 \mu \mathrm{g} / \mathrm{m}^{3}$. For local adverse dispersion conditions, that occurred $6 \%$ of the time, odour from the landfill occurred in residential areas around the landfill. At these conditions the dispersion models gave half hourly concentrations of about $14 \mu \mathrm{g} / \mathrm{m}^{3}$ in one of the living areas. In conclusion it was stated that $\mathrm{H}_{2} \mathrm{~S}$ also could be used as an indicator for any odour problem occurring around landfills of this kind.

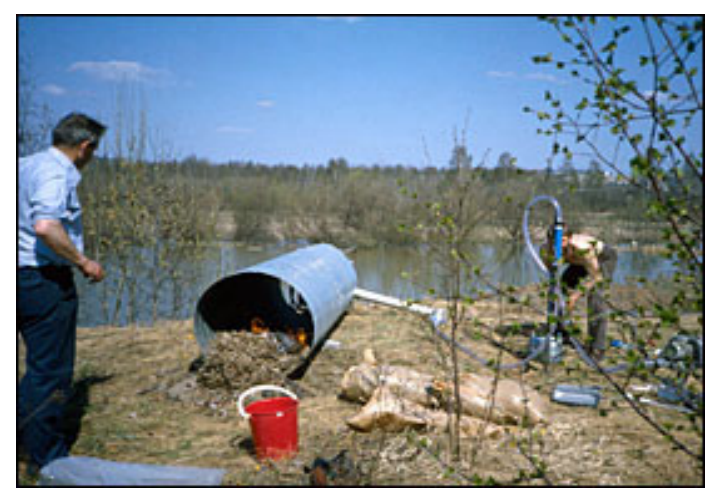

Figure 1: The experimental layout of measuring emissions from bonfires and burning of rubbish.

\subsection{Burning of garden waste}

Emissions to the atmosphere from ground level open burning are affected by many variables, including wind, ambient temperature, composition and moisture content of the debris burned, as well as compactness of the pile. In general, the 
relatively low temperatures associated with open burning increase emissions of particulate matter, carbon monoxide, and hydrocarbons and suppress emissions of nitrogen oxides. Emissions of sulphur oxides are a direct function of the sulphur content of the material burned.

Field experiments were undertaken at NILU to study the amount of particles and polycyclic aromatic hydrocarbons (PAH) emitted when typical garden debris was burned in Norway (NILU [14]). PAH may be formed by the thermal decomposition of any organic material containing carbon and hydrogen. More than $30 \mathrm{PAH}$ compounds and several hundred PAH derivatives have been identified to have carcinogenic and mutagenic effects, making them the largest single class of chemical carcinogens known (Bjørseth and Ramdahl [4]).

In smoke from garden deposits it was found that the emission rates of $\mathrm{CO}$ could be as much as 3 to 4 times the emission rate from an idling car. Ten kilos of garden debris gave the following emissions to the atmosphere:

- $1 \mathrm{~kg}$ Carbon monoxide (CO)

- $1 \mathrm{~kg}$ PM (soot and ash)

- $25 \mathrm{~g}$ Aldehydes

- 5 g Polycyclic Aromatic Hydrocarbons (PAH)

PAH compounds have been studied in many countries. Fang et al. [8] found that the total PAH concentration in smoke from biomass burning ranged from 7 to $46 \mathrm{ng} / \mathrm{m}^{3}$. The highest value of $\mathrm{B}(\mathrm{a}) \mathrm{P}$ was measured at $3 \mathrm{ng} / \mathrm{m}^{3}$ while the lowest was at the same site $0.1 \mathrm{ng} / \mathrm{m}^{3}$. These values are comparable to those measured at street level in urban centres such as Hong Kong.

Emissions of suspended particles have been investigated and reported over a number of years. Darley et al. [1] carried out both laboratory and field studies and concluded that moisture content of fine fuel residues was the most significant factor influencing emission levels.

At good burning conditions the particulate emission factors for some crops were:

- Orchard pruning, citrus, almond, grape $2-4 \mathrm{~g} / \mathrm{kg}$

- Rice, barley, wheat $3-5 \mathrm{~g} / \mathrm{kg}$

- Russian thistle

- Asparagus

$10-13 \mathrm{~g} / \mathrm{kg}$

$14-20 \mathrm{~g} / \mathrm{kg}$

\subsection{Agricultural waste}

Organic refuse burning consists of field crops, wood, and leaves, and the emissions are again dependent mainly on the moisture content of the refuse. In the case of the field crops the emission rates depends upon whether the refuse is burned in a head fire or a backfire. Head fires are started at the upwind side of a field and allow to progress in the direction of the wind, whereas backfires are started at the downwind edge and forced to progress in a direction opposing the wind.

Emission factors for open air burning of agricultural waste are presented in Table 1 as a function of the type of waste. The emission rates may also be a function of burning techniques and/or moisture content. 
Hays et al. (2005) indicated that the $\mathrm{PM}_{2,5}$ mass emission factor from burning of wheat and rice were $4.7 \pm 0.04$ and $13.9 \pm 0.3 \mathrm{~g} / \mathrm{kg}$ of dry mass respectively.

Table 1: Emission factors $(\mathrm{g} / \mathrm{kg})$ for some selected compounds when burning different type of agricultural waste.

\begin{tabular}{|l|c|c|c|c|c|c|c|}
\hline Type of waste & PM & $\mathbf{P M}_{\mathbf{1 0}}$ & $\mathbf{P M}_{\mathbf{2 , 5}}$ & $\mathbf{S O x}$ & $\mathbf{N O x}$ & $\mathbf{C O}$ & $\mathbf{V O C}$ \\
\hline Municipal refuse 1) & 8 & & & 0.5 & 3 & 42 & 6.5 \\
\hline Open air refuse 3) & 37 & 37 & & 0.5 & 3 & & \\
\hline Agricultural waste 3) & 10 & 5 & & & & & \\
\hline Rice1) 2) & 4 & 3.7 & 2.9 & 0.6 & 2.6 & 29 & 3 \\
\hline Alfalfa 2) & & 14.5 & 13.6 & 0.3 & 2.3 & 60 & 12 \\
\hline Canopy \& shrubs2) & & & 10.7 & & & & \\
\hline Grassland 2) & & 8.0 & 7.6 & 0.3 & 2.3 & 57 & 5.5 \\
\hline Forest 2) & & $10-15$ & $8-14$ & 0.05 & 1.8 & $75-150$ & 10 \\
\hline
\end{tabular}

1) Jenkins, [12] AP42 2) Gaffney [9] 3) Larssen et al. [13].

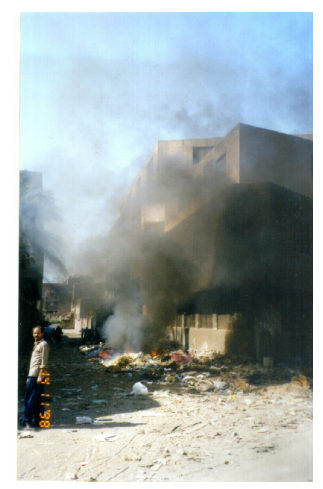

Figure 2.

\subsection{Municipal waste burning}

In contrast to municipal combustors, which operate under highly controlled conditions designed to reduce formation and emission of air pollutants, backyard trash burning is uncontrolled. The low temperature burning and smouldering conditions typical of backyard trash fires promote the formation of air pollutants including polychlorinated dibenzodioxins and dibenzofurans, sometimes collectively called "dioxins", fine particulate matter and PAHs. These pollutants form during backyard trash burning regardless of the composition of the material being burned.

In 2001 a typical US County processes approximately 400,000 tons of waste/yr with an estimated emission rate of about $200 \mathrm{ng}$ dioxins per $\mathrm{kg}$ waste. This is equivalent to $72.6 \mathrm{~g} / \mathrm{yr}$ of dioxins from backyard trash fires if all trash were domestically burned (Chlorine Chemistry Council [6]). 


\section{Concentrations and impacts}

Burning of trash and biomass such as leaves and wood is common practices throughout most of the developing countries. The impact to people in these areas is mainly due to high concentrations of $\mathrm{PM}_{2,5}$ and $\mathrm{PM}_{10}$ which also contain toxic and carcinogenic elements. Biomass burning often takes place after sunset, when the atmospheric dispersion conditions are poor. Very high concentrations of PM and other pollutants are measured in the smoke during these conditions.

The relative contributions to the total PM exposure have been estimated in several cities around the world. In Mumbai the contribution from refuse burning to the total $\mathrm{PM}_{10}$ urban exposure has been estimated to about 26\% (Larssen et al. [13]). Samples of PM were collected in a semi-residential area of Dhaka and in an urban area of Rajshahi, a city in northwestern region of Bangladesh. In Rajshah it was found based on receptor modelling that biomass burning contributed about $50 \%$ of the $\mathrm{PM}_{2,5}$ mass (Begum et al. [2]). A number of source apportion studies have indicated that biomass burning often represents 30 to $50 \%$ of the total PM load.

\subsection{Concentrations downwind from back yard burning}

Model estimated downwind concentrations of $\mathrm{PM}_{10}$ are presented in Figure 3 based on emissions of particles as a result of open air burning.

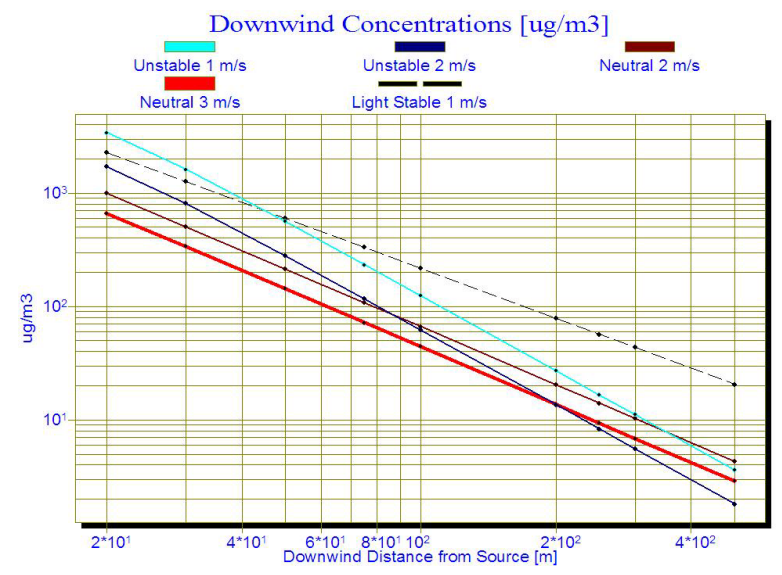

Figure 3: Estimated concentrations of $\mathrm{PM}_{10}$ downwind from open-air burning of backyard waste.

Assuming that a small waste dump is set on fire and that about $10 \mathrm{~kg}$ of waste is being burned during one hour the estimated emission rate of $\mathrm{PM}_{10}$ at around $0.1 \mathrm{~g} / \mathrm{sec}$ may lead to concentrations of $\mathrm{PM}_{10}$ in the smoke plume around $100 \mathrm{~m}$ away from the fire of between 80 and $200 \mu \mathrm{g} / \mathrm{m}^{3}$ depending on meteorological conditions. 
At a distance of $200 \mathrm{~m}$ from a small bonfire of this kind the one-hour average concentration of $\mathrm{PM}_{10}$ may still be $20-30 \mu \mathrm{g} / \mathrm{m}^{3}$ during neutral atmospheric conditions and up to $80 \mu \mathrm{g} / \mathrm{m}^{3}$ in light stable conditions. The latter case is typical for the effect of open-air burning that is taking place in developing countries at sunset or in the early evening.

\subsection{High $\mathbf{P M}_{10}$ concentrations from agricultural waste burning}

Measurements of suspended particles in Cairo were undertaken during the season when rise waste and other agricultural waste were burned in the Nile Delta. Measurements in Cairo was taken downwind from these sources, and it has been shown that the burning of waste contributed considerably to the general air pollution load in Cairo, several tens of kilometres downwind (Sivertsen and Dreiem [15]).

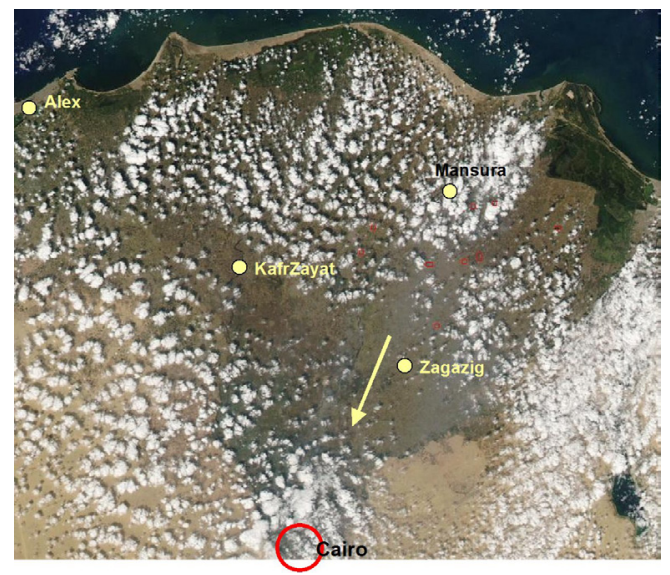

Figure 4: A satellite photo taken on 11 October 2004 shows plumes from burning of agricultural waste in the Nile Delta. The wind transported the plumes towards the city of Cairo.

On 11 to 12 October 2004 very high concentrations of $\mathrm{PM}_{10}$ were recorded at the monitoring stations at Abbaseya and at Fum-AlKhalig in Cairo as seen in Figure 5. The winds were from the north at $2 \mathrm{~m} / \mathrm{s}$ at night and in the morning hours. Plumes of dust were observed moving into Cairo in the morning of 11 October 2004. The site Fum AlKhalig is located in the northern part of Cairo (closest to the Nile Delta) and hourly average $\mathrm{PM}_{10}$ concentrations exceeded $400 \mu \mathrm{g} / \mathrm{m}^{3}$ at this site

Gertler et al. [10] performed a source attribution study (SAS) to determine contributions from various sources in Cairo. Samples of $\mathrm{PM}_{10}, \mathrm{PM}_{2,5}, \mathrm{PAH}$, VOC were collected on a 24-hour basis to identify the importance of the burning of agricultural waste in the Delta. At a site in northern Cairo, close to the Delta, $\mathrm{PM}_{10}$ contribution from burning was estimated at $40 \%$, for $\mathrm{PM}_{2,5}$ the contribution 
was $30 \%$. Inside the city centre the open-air burning contribution was estimated at $42 \%$ both for $\mathrm{PM}_{2,5}$ and $\mathrm{PM}_{10}$.

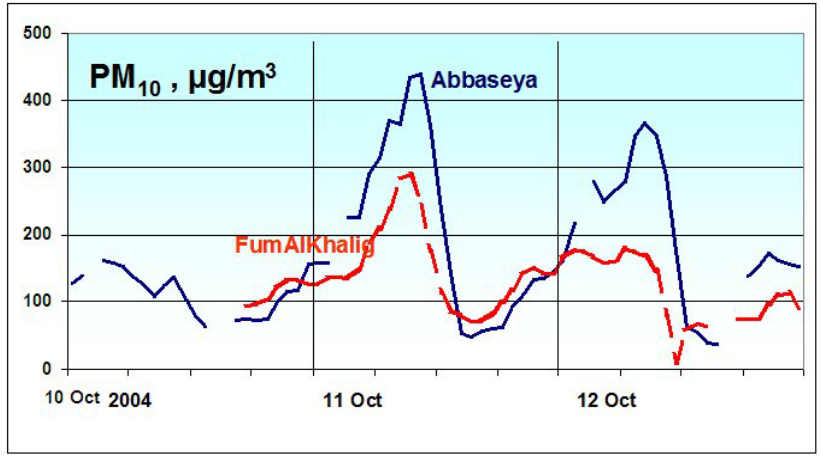

Figure 5: $\quad \mathrm{PM}_{10}$ concentrations measured at Abasseya (north Cairo) and Fum AlKhalig (city centre) from 10 to 12 October 2004.

\section{Conclusions}

Leakages of gases from waste dumps have been shown to include a number of odorous compounds. Measurements undertaken in Norway indicated that $\mathrm{H}_{2} \mathrm{~S}$ and Ethyl Benzene had contributed to bad smell.

Burning of waste and biomass produces PM, PAH, dioxins and a number of toxic air pollutants. Concentrations downwind may frequently exceed limit values and air quality standards.

Air pollutants from biomass and agricultural burning have been demonstrated to contribute 30 to $50 \%$ to the general PM exposure in urban areas dependent upon weather conditions.

\section{References}

[1] Darley, E.F., Miller, G.E., Coss, J.R. and Sisswell, H.H. (1974) Air pollution from forest and agricultural burning. Berkeley, University of California (Project report 2-017-1).

[2] Begum, B.A., Kim, E., Biswas, S.K. and Hopke, P.K. (2004) Investigation of sources of atmospheric aerosol at urban and semi-urban areas in Bangladesh. Atmos. Environ., 38, pp. 3025-3038.

[3] Bennett, G.F., (1987) Air quality aspects of hazardous waste landfills. Hazard. Waste Hazard. Mat., 4, 119-138.

[4] Bjørseth, A. and Ramdahl, T., (1985) Sources of emissions of PAH. In: Bjørseth A., Ramdahl T. (Eds.), Handbook of polycyclic aromatic hydrocarbons, Vol. 2, New York, Marcel Dekker, pp. 1-20.

[5] Braathen, O.A. and Schmidbauer, N. (1989) Mapping emissions to air from Grønmo landfill. Lillestrøm (NILU OR 55/89) (In Norwegian). 
[6] Chlorine Chemistry Council (2004) Backyard trash burning: the wrong answer.

URL:

http://c3.org/chlorine issues/understanding dioxin/trash burning.html.

[7] Cooper, C.D., Reinhart, D.R., Rash, F., Seligman, D. and Keely, D. (1992) Landfill gas emissions. Gainesville, Florida center for solid and hazardous waste management (Report no. 92-2).

[8] Fang, M., Zheng, M., Wang, F., To, K.L., Jaafar, A.B. and Tong, S.L. (1999) The solvent-extractable organic compounds in the Indonesia biomass burning aerosols characterization studies. Atmos. Environ., 33, pp. 783-795.

[9] Gaffney P. (2000) Emission factors compiled by California Air Resources Board. URL: http://www.arb.ca.gov/smp/techtool/arbef.pdf.

[10] Gertler, A.W., Abu-Allaban, M. and Lowenthal, D.H. (2004) Measurements and sources of $\mathrm{PM}_{10}, \mathrm{PM}_{2,5}$, and VOC compounds in greater Cairo. Presented at the 13th World Clean Air \& Environmental Protection Congress and Exhibition, 22-27 August 2004, London, U.K.

[11] Hays, M.D., Fine, P.M., Geron, C.D., Kleeman, M.J. and Gullett, B.K. (2005) Open burning of agricultural biomass: Physical and chemical properties of particle-phase emissions. Atmos. Environ., 39, pp. 67476764.

[12] Jenkins, B. (1996) Atmospheric pollutant emission factors from open burning of agricultural and forest biomass by wind tunnel simulations, April 1996, Davis, University of California (CARB Project A932-126).

[13] Larssen, S., Gram, F., Hagen, L.O., Jansen, H., Olsthoorn, X., Aundhe, R.V., Joglekar, U., Mehta, K.H. and Mahashur, A.A. (1995) URBAIR. Urban air quality management strategy in Asia. Greater Bombay. City specific report. Kjeller (NILU OR 56/95).

[14] NILU (2003) Effects of burning bonfire and burning of rubbish. NILU Fact sheet (NILU 3/2003 N). URL: http://www.nilu.no/index.cfm?ac=topics\&text id $=7560 \&$ folder $\mathrm{id}=4580$ \&view=text (In Norwegian).

[15] Sivertsen, B. and Dreiem, R. (2004) DANIDA. EIMP phasing-out phase, 2003-2004. End of mission report, air quality monitoring, mission 05, October 2004. Kjeller (NILU OR 76/2004).

[16] Tønnesen, D. (2001) Estimated emissions and dispersion of odours from a waste disposal area. Kjeller (NILU OR 70/2001) (In Norwegian).

[17] U.S. EPA (1996) AP42 Emission Factor Database. U.S. Environmental Protection Agency.

[18] Young, P.S. and Parker, A. (1983) The identification and possible environmental impact of trace gases and vapours in landfill gas. Waste Man. Res., 1, 213-226. 